\title{
CAUSE AND EFFECT RELATION BETWEEN THE CURRENT MIGRATIONS AND TERRORISM IN WESTERN EUROPE
}

\author{
Nedeljko Cvetković ${ }^{1}$ \\ Academy for National Security, Belgrade \\ Danilo Vujović
}

\begin{abstract}
The key subject analyzed within this article - the existence, and character, of the cause and effect connection in regard to the current migrant crisis and the rise of terrorist activity in Western Europe - required first a look back at the terms terrorism and migration, their respective characterisitics, as well as the geopolitical factors affecting them; secondly, it required an analysis of their mutual interaction; and finally, a comparison of the points of view taken by all the parties involved when approaching this problem, as well as determining certain potential solutions to the myriad of problems caused by the migrant crisis. This subject, we feel, is relevant due to the important role terrorism has in causing the migration of muslim population from Africa and the Middle East toward the European Union, as well as the potential effect of the said migration on the spreading of terrorism within Europe itself. Whilst researching the literature needed to write this article, the authors used the method of content analysis. Existence of the direct link between terrorism - as one of the causes of migrations, and migrations - as a condition helping the expansion of terrorism into Europe, presents itself as a result of the conducted research.
\end{abstract}

Keywords: terrorism, migration, radicalization, transfer of violence, infiltration.

\section{INTRODUCTION}

Among the security risks facing the modern states, terrorism takes one of the spots at the very top of the list. It could be said that it even surpasses the dangers such as nuclear or world war, if for no other reason than for the fact that these armed conflicts are only potentail threats, which present almost equal dangers for both parties involved, while terorrism stands as a very real form of risk,

1cvele1981@gmail.com 
which carries of its share of lives almost daily (Statista, 2017) ${ }^{2}$.

What makes terrorism especially problematic from the standpoint of those tasked with fighting it is the all too often inability of determining one's opponent, meaning that a terrorist act can be carried out by almost anyone. At times, it takes only one person to cause the chaos of terrorist strike, like the one that happened in Nice on July 14th, 2016 (BBC, 2016) ${ }^{3}$. Combating this type of warfare - for which we can safely say that it will be even more present in the future, since the nuclear potential of the most powerful of the worlds states will keep the status-quo when speaking of the open conflict of wider scales, is largely down to successful prevention of the escalation of violence. However, it is not enough to just act repressively in order to prevent future terrorist acts; we have to deal with long-term structural solutions that address the problems triggering the very appearance of terrorism. (Zwitter, 2011: 7-13)

Prevention depends on a multitude of factors, ranging from the economic and geopolitical situation, through social relations in individual countries - whether it is the countries from which the terrorists come from or those they are heading for; to the financial and numerical powers of the agencies that fight terrorism. Not even science itself has a unique position on this phenomenon. The definitions include everything from the strategy of political communication for the psychological manipulation of masses by which unarmed civilians (and persons

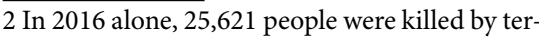
rorists. See: "Number of casualties due to terrorism worldwide between 2006 and 2017"

3 Mohamed Lahouaiej Bouhlel is a typical example of the perpetrator of a terrorist act that has been radicalized over the Internet and was working alone. who do not participate actively in armed conflicts, such as prisoners) are deliberately chosen for victims to impress third parties (Schmid, 2016:14), through the spreading of fear and panic (Dragojlović, Jovanović, 2016: 65), to those stating that terrorism is carried out by a subnational or non-state entity (Hoffman, 1998:43). Common to all definitions of terrorism as a concept is that it is aimed at achieving a political-interest objective and that its perpetrators primarily use violence to create an atmosphere of fear in order to achieve the goals of the organization behind them.

Since terrorism is often a reaction to the conflicts of the unequals, such as those in Iraq and Afghanistan since the beginning of the 21st century (Stern, McBride, 2003) and the current one in Syria, meaning that the agents of terrorism have an opponent that is more powerful than them, for the success of the terrorist act the anonymity of the perpetrator until the implementation phase is crucial. Anonymity also brings with it the fact that even less courageous and marginal groups can be motivated to commit a terrorist act, since the fear of retribution and punishment is significantly reduced (Silke, 2003:85). With this in mind, over the past several years, and especially with the exacerbation of the conflict in the Arab world, migration to the European Union has grown into a very serious security challenge ${ }^{4}$ (Mijalković, 2016:5).

Migrations themselves, if we define them as entering [immigration] or ex-

4 It is estimated that in 2005 some 175 million people in the world had the status of an international migrant, in 2013 there were around 214 million, 2016, there are more than 224 million. A logical conclusion is that migrations evolved, and that they also evolved the risks and threats of migration to the security of people, states and international communities. 
iting [emigration] by (groups of) people from one or another, usually a very distant, location with the intention of settling there, permanently or temporarily, pose a challenge to the security of all states on the route they encompass. Whether voluntary or involuntary, legal or illegal, they involve the need for, primarily security, control of persons participating in them, whether they are leaving or entering a country (Schmid, 2016:14). The current refugee crisis, whose roots can be traced back to the "period between 2007 and 2011 when the first major groups of migrants from Africa and the Middle East started on the EU path" (Gajić, 2016:81), has raised this need to an even higher level since it carries a great potential risk of the presence of anonymous terrorist agent among the refugee population. The risk of the possibility that among the sea of refugees, set in motion by the conflicts with a clear stamp of Islamist terrorist organizations, there is even one member of these organizations is not something that the country in which they immigrate can accept.

In a world under pressure from the threat of a nuclear war, migration can be a major security challenge (Simeunović, 2015:7). The interconnectedness of these two phenomena, whether one causes another or they overlap each other, must be at the very center of interest for both science and the security agencies of all countries.

\section{TERRORISM (VIOLENCE) AS A TRIGGER FOR MIGRATION}

When speaking about the security challenges that the problems of terrorism and migration carry, we can no longer talk about individual countries and their approach to solving the given problems. The world has long since passed such a framework of considerations. According to A. Gajić, both of these phenomena must be evaluated as "accompanying the globalization" (Gajić, 2016:77). In his presentation, Gajić focuses on the "migration and fate of migrants" (Gajić, 2016:77), but if we look at the facts, we will see that countries like Syria, Iraq and Afghanistan, which are the scene of armed conflicts and a large number of terrorist attacks, are also some of the biggest refugee sources (de Wenden, 2016:118), and thus the link between migration and terrorism becomes clearer.
In the context of globalization, which leads to the intensification of social relations on the world stage, connecting distant places in such a way that the events that have taken place miles away influence local events and vice versa (Giddens, 1988:69), the old conflicts between East and West gain a completely new form. The disbalance that emerged in the field of military and political power with the fall of the Berlin Wall, led to a situation in which the West, led by US military and NATO, found itself in a global conflict with terrorism, especially Islamist, after the September 11, 2001.

As Islamist terrorism, which has its roots in the jihadist movement, which is experiencing an expansion with the Soviet-Afghan conflicts of the 1980s (Neumann, 2014: 9) ${ }^{5}$. with the arrival

5 The Jihadist movement advocates and justifies armed struggle and brutal acts of violence, while diminishing the importance of the spiritual and 
of the 21st century, assumed the place of the leading danger to global security, whether it was "internal or international” (Dragojlović, Jovanović, 2016:63) the focus of the conflict transferred to the territories of the countries of the Middle East (Voronkova, 2017: 5) ${ }^{6}$ and North Africa. US interventionism, with the support of NATO, had, at least as an official, task to root out terrorism and bring democracy to the then authoritarian regimes. Whether the justification that the West used after the 2001 US attacks hid oil or some other state or corporate interest, is a question that does not have an answer, at least not a definite one.

What can, however, be said with certainty is that foreign interventions often make bad situations worse, prolong conflicts and lead to asymmetric tactics of resistance groups - including terrorism (Schmid, 2016:29). In Iraq alone, where the international coalition has systematically reduced the ISIS territory, the number of victims of terrorist attacks in 2016 rose more than anywhere else in the world, with 2,800 more deaths than the previous year (Institute for economics \& peace, 2017: 18). In addition to the escalation of terrorism and related violence, a phenomenon that also follows international military interventions are refugee crises (Schmid, 2016: 47) ${ }^{7}$.

non-violent version of jihad, for the defense of Muslim countries and the liberation of the ummah. The movement represents salafistic teaching, which promotes the extremely narrow and puritanical interpretation of the Sunni Islam, imposes its own vision of society and rejects every kind of human laws and democracy.

6 The war in Syria with 50,000 new victims in 2016 reached a figure of about 290,000 since 2011, while the conflicts in Iraq and Afghanistan in 2016 added to their own number of victims another 17,000 , or 16,000 lives.

7 The overreaction of the US and intervention in Iraq in 2003 (when Saddam Hussein was wrongly accused of supporting $\mathrm{Al}$ Qaeda and possessing weapons of mass destruction) alone, directly or indirectly led to the deaths of between
Although terrorism can be seen as a protest against foreign intervention by the individual states (Robbins, 2017), the supranational coalitions and the leading Western countries and their military actions are not the only ones responsible for the intensification of conflict on both military and political scene. Political and media factors are very important, often synergistically influencing the development of the geopolitical situation.

The weakness of the state as a system in the Middle East, Afghanistan and North Africa, shown in the political, economic and social instability, opened the way, through internal conflicts and external interventions, for various forms of violence, violation of human rights and the destruction of material and cultural goods. In such a situation, it is not surprising that the answer by the widest civilian population have been the mass migrations, primarily towards Western Europe (Beriša, Rakić, 2016:36).

Terrorism, as it consciously attacks the civilian population, is one of the most influential causes of international migration. The greater the number of terrorist acts in a country and the higher the rate of mortality as a consequence of the same, the greater the number of people migrating from that country (Hasan, 2018) ${ }^{8}$. From this point of view, we can classify terrorism as a so-called "push" factor, that is, the one that starts $\mathrm{mi}^{-}$

137,000 and 165,000 civilians and internal displacement around 1,300,000 people, as well as the creation of more than $1,400,000$ refugees. The US intervention in Afghanistan and attacks across the border with Pakistan after September 11, 2001 cost about 26000 and 21500 civilians ... The population of Afghan refugees in Pakistan is around 1500000 documented people.

8 With nearly 600,000 registered refugees from Syria in 2017, their total number in Turkey has risen to $3,400,000$. Only a small portion of them managed to continue migration to Western Europe. See: Hasan, H., "What awaits Syrian refugees in 2018?". 
grants from their previous environment (Gajić, 2016:77). However, terrorism is not the only phenomenon that affects the emergence of migration; the terror of the government, as well as economic and environmental factors can largely be responsible for the international movement of the population.

When we talk about a "weak state" as a favorable ground for terrorist organizations, and the growth of their impact on the movement of the population, it should be said that these are countries that either support terrorism, such as the Taliban regime in Afghanistan from 1996 to 2001, or are, like Lebanon, too weak to oppose it. The third type of environment in which terrorism can be the trigger of migration is a terrorist proto-state, such as the ISIS, from whose territories by July 2017 , international refugees or those internally displaced, totaled over $8,000,000$ people (BBC, 2018) ${ }^{9}$.

Under these circumstances, terrorism can trigger three types of population response: fighting, fleeing and hiding (Schmid, 2016:16). For us, certainly the most interesting is the most common one (whenever there are conditions for it), which is flight, ie migration. It is a

9 Over 5,500,000 Syrians have left the country, while 2,800,000 Iraqis have been internally displaced since the ISIS conflict. rarity that an isolated terrorist act causes a massive population movement, but within "weak states" the civilian population is almost always exposed to a series of brutal terrorist attacks.

Such serial attacks, characterized by non-discriminatory violence, lead to fear among the population and the natural need to move away from the source of danger. Such a reaction is often exactly what the perpetrators are attacking and expecting. There are indications that ISIS has not only attempted to tax migrants and thus fund further terrorist acts, but also through the refugee flows tried to infiltrate its fighters, especially returnees from other battlefields, which is a huge challenge for the security of the European countries which these migrants are striving to reach (Schmid, 2016:28).

Whether we are talking about migration as a planned consequence of terrorist acts or just as a follow-up phenomenon in the states that are affected by a high degree of terrorist activity, it is clear that terrorism and migration are in a causal relationship. What we can also claim is that both phenomena are closely linked to the absence of a powerful state apparatus, especially in the countries of the Arab world.

\section{MIGRATIONS - A TRANSIT OF VIOLENCE}

In the conditions of the migrant crisis, which has been threatening the world's security outlook for almost a decade, the media have become extremely effective weapons in creating a xenophobic environment. Whether it is Silvio Berlusconi who declares that western civilization is superior to Islamic (Pavlićević, 2016:65),
Viktor Orban, who takes for himself the position of the defender of Christianity and raises the wall at the border, or the Tramp that recognizes Jerusalem as the capital of the city in an already very heated atmosphere (Wilson center, 2017) ${ }^{10}$,

10 Although the US media and administration emphasize that this is a cessation of the US's "double game" with Israel and Palestine, it is a 
the demarcation line between "us and them" becomes clear. The animosity towards Muslims in Europe is affirmed primarily by the right-wing or extreme right, which sees them as a threat to European culture, and, in contrast to the official stance of the EU which implies tolerance, regards them as deviant, enemies and terrorists (Pavlićević, 2016:64).

The other side does not lag behind in this fight. One of the goals of the terrorist organizations is the free access to the world media system through public violence, which is always reported (Schmid, 2016:16). The escalation of conflicts and social polarization, which terrorists are striving for, are also pulling a precise line between friends and enemies, so ISIS claims that it is the personal duty of all Muslims to migrate to Caliphate (Schmid, 2016:3), while all those who leave it are treated as infidels. The Internet and social networks open endless possibilities of publishing various messages, as well as radicalization and recruitment of new fighters, especially among the young Muslims from the West. "The German newspaper, Deutsche Welle, states that about 400 jihadists from Germany are fighting on the side of the ISIS, and that this number is unofficially over 1800 militants" (Despotović, 2016:21), which is sufficient proof of the efficiency of the Internet in the hands of terrorists.

Terrorist organizations are also benefiting from the fact that, after the fall of the Arab Spring, many Muslims have become convinced that nonviolent change is not possible (Parezanović, 2012) ${ }^{11}$. In

clear risk that such a move would further distance Mahmoud Abbas from the negotiating table.

11 According to Marko Parezanovic, Syria is a classic example for a theoretical analysis of the phenomenon that manifests itself when a failed political upheaval turns into a more complex such an atmosphere of hostility, we can expect only further spreading of the conflict. In addition to the existing one toward the EU the new direction of terrorist activity could be towards the north and Russia, especially after the serious involvement of Russia in the conflict in Syria (Dnevnik.hr, 2017) ${ }^{12}$.

The extent of migration from the turmoil and war affected countries of North Africa and the Middle East, whose alarming peak reached in 2015 , again draws the attention of the world, and especially the public in Europe - as a primary participant in the process of caring for the migrants and neutralizing the negative effects of this social phenomenon. The significance of this and the accompanying phenomena is best seen in the UN estimation that there are currently 71 million different migrants in Europe (Simeunović, 2017:32). These numbers are only likely to grow in the foreseeable future (Kern, 2017) ${ }^{13}$.

The movement of the peoples in its various manifestations has characterized human history since its creation. Looking at the "closer" past (post-Cold War period), migratory movements, as A.

form of social conflict, such as terrorism, the guerrilla action, or an armed conflict of wider proportions.

12 "The coalition led by America, supported by the Syrian army and Russia, has thrown out the Islamic State from Syria and Iraq, its post-war strongholds, after which many ISIS fighters ended up in Avanistan, warns Zamir Kabulov, head of the Middle East Department of the Russian Ministry of Foreign Affairs. "Russia was among the first countries to warn of the expansion of ISIS in Afghanistan. Lately, the Islamic State has increased the presence in that country. According to our estimation, their strength counts more than 10,000 combatants, and they continue to grow. This includes new fighters who gained experience on the battlefields in Syria and Iraq, "Kabulov told RIA Novosti".

13 The Muslim population in Germany could rise to 20 million by 2020 , according to the president of the Bavarian Association of Local Governments Uwe Brandl. 
Schmid emphasizes, can be seen through the prism of numerous factors among which he highlights the following:

a) Unequal distribution of wealth at global level - one percent of people own as much as the rest of human population,

b) A demographic explosion of the population combined with economic stagnation, with the population rising faster than the economy, which is particularly characteristic of parts of Africa and the Middle East,

c) Mass global unemployment (currently $200,000,000$ people according to the ILO's estimates) and the emergence of an even more massive "working poor" category (income of employees below the border for the smooth functioning of individuals and families),

d) Environmental degradation (characterized by floods, desertification, forest destruction, water shortages in large measure, uncontrolled exploitation of natural resources in countries of origin of migrants) (Miljlković, Petrović, 2016:2) ${ }^{14}$,

e) Changes in the tactics of warfare that have transformed the civilian population into the main target, creating internal and external migration movements within countries affected by the conflict,

f) The re-emergence of exclusive nationalism and the rise of religious intolerance, which cause ethnic and religious cleansing,

g) A technical and technological revolution in transport that allows mass migration over long distances,

14 "Due to serious and permanent degradation of the environment due to pollution, natural or technical-technological disasters, the existing living environment makes it impossible for the population to live and work, or makes the life of the population difficult and problematic with numerous health problems." h) The expansion of smuggling and trafficking of humans as a highly profitable, low-risk business by organized crime, which provides false papers, transport, entry and exploitation to those who are capable and willing to pay (Mijalković, Petrović, 2016: 3) ${ }^{15}$,

i) The presence of ethnic diaspora in "global cities" abroad that make bridges for voluntary legal migration (eg through family reunification) and illegal migration (eg through trafficking in human beings, employment in an illegal or "black" labor market) (Schmid, 2016:15; Mijalković, Petrović, 2016: 6) ${ }^{16}$.

The current migrant crisis has consequences for three continents, bringing with it the appearance of a new form of migration movements "the family migration" (Mihić, 2016:111). ${ }^{17}$ We should add to this the fact that the largest number of migrants come from Syria, Iraq and Afghanistan, the territories that represent the fertile ground for the operation and development of terrorist organizations, and their focused radicalization of youth (Lečić, 2017:107; Čerin, $2017)^{18}$. The danger of possible infiltra-

15 It is claimed that this is, behind only trafficking in narcotics and weapons, the most cost-effective crime-organized business that, just since the beginning of this century, makes a billion dollars a year in Europe, with the minimal risk.

16 The consequences of mass migrations are the destabilization of the existing national labor markets due to the massive inflow of new labor. At the same time, these new so called black labor markets, which destabilizes the legal labor market, public finances and the state budget, also "jeopardize" the existing black labor markets.

17 The percentage of women and children transiting into EU countries during the previous year (2015) was unrecorded in recent human history. 18 These claims are supported by the German media's reports of the attempts by a 12 -year-old boy of Iraqi descent to install an explosive device at a New Year's fair in Ludwigshafen (a person believed to be the youngest person in Europe arrested for suspicion of planning a terrorist act) ... ... Then the arrest of two boys aged 15 and 17 in the southern German province of Baden-Württemberg, who planned armed attacks around 
tion (in a new form of migration movement) of indoctrinated and radicalized members of this part of the population is significant (Čerin, 2017) ${ }^{19}$.

A special security challenge is illegal migration movements (smuggling of migrants and human trafficking), whose fluctuation is accompanied by continuous recruitment, illegal transportation and reception in the countries of destination by criminal organizations (Mihić, 2016:111). This leaves additional space for radicalized members to continue covert activities outside the "scanner" of the security sector, as well as the possibility of upgrading already established links in criminal circles by linking to illegal arms, documents and narcotics markets (Schmid, 2016: 8) 20. $^{20}$

Taking into consideration the essence of migration, we note that they carry a security risk (they destroy national borders, change the ethnic, age, religious, educational and working structure of the population, increase crime rates, abuse social programs, are followed by the boycott of the host country culture, and impose their own way of life arising from the religious and social conditions in the country of origin ...) of further increased infiltration of radicalized members of terrorist organizations. The investigation, which was conducted after the attack in Paris in 2015, shows that a
Syrian citizen who took part in it had passed through the Balkan route and the Republic of Serbia in October 2015 (Lečić, 2017:109). In addition, coming from the war-torn area of the Middle East, Nabil Fadli, a suicide bomber who killed ten German tourists on the Sultan Ahmet Square in Istanbul on January 12, 2016, entered the country as an asylum seeker a week earlier. Tunisian Valid Salihi, whose registration was carried out at a reception center in Germany, attacked a police station in Paris on the occasion of the anniversary of the attack on the newspaper, Charlie Ebdo (Mijalković, 2016:28). The cases above are examples of the abuse of the migratory population for infiltration of the radicalized members of terrorist organizations (See, 2018: 9) ${ }^{21}$, by which the transfer of violence into the territory of a centuries-old enemy is carried out. The migrant population, one part of it that is, carrying its past with itself, brings animosity that can lead to new conflicts, which significantly increases the danger of terrorist activity. Special responsibility lies with the host country, which must make adequate efforts to achieve the social integration of migrants, especially in avoiding any form of segregation, which would make it easier for the various extremist groups to become involved.
Frankfurt.... French authorities arresting three 15-year-olds linked to jihadists and planned attacks last year... ... In Austria, fourteen six-yearolds were recruiting their peers on behalf of the Islamists.

19 According to State Department PR member John Kirby, ISIL originally used children in the collecting information, and is now using them to commit suicide attacks. Kirby added that in the first three months of 2015, ISIL recruited and trained 400 children for fighting.

20 At one point in 2015 , only 25 to 30 percent of refugees arriving in Germany had passports or other valid documents.
21 A problem apart is the returnees from the Middleeastern battlefields, who in large percentage show unpredictability in behavior, due to the fact that a significant proportion of them suffer from PTSD. They are candidates for direct or indirect terrorist action under the socalled "lone wolf" principle, as well as potential agents of radicalization of other persons and other operational and technical tasks. Also, the so-called "veteran's effect" makes the terrorist acts, implemented by these persons, have a greater chance of "success" and a greater number of victims. 


\section{POSSIBLE EU RESPONSES TO THE SECURITY CHALLENGES OF THE MIGRANT CRISIS AND THE DETECTION OF THE RADICALIZED PART OF THE MIGRANT POPULATION}

Adequacy of the response to the enormous extent of migration movements and interactively connected terrorism are often determined by two criteria: acceptability within general democratic principles and success in problem solving. Measures that can be successful are often unacceptable (for example, the raising of the fence by Hungary on the border with Serbia secured by the army and police or the raising of the fence on the Austrian border by Germany), on the other hand, the measures that are acceptable to our democratic principles are often unsuccessful (for example, when terrorism-related persons are provided with the full protection of the democratic system) (Sedeberg, 2002:267-284).

\section{Consensus policy}

The current crisis further deepens the inability to achieve a unified political position within the European Union, followed by various disagreements between members, diplomatic incidents, ${ }^{22}$ as well as the boycott of Hungary, Slovakia and increasingly hard attitude bt Poland in regard to the number of migrants they are ready to accept on their territory. An

22 There have been protests on several occasions by Hungary and Croatia towards Serbia, Slovenia towards Croatia, Austria towards Slovenia and Croatia, as well as constant disagreements between Greece and Macedonia, and others. adequate response to a migrant crisis that will, in the future, continue to burden Europe, should be sought in a policy of consensus. The number of migrants to be received by individual members should be aligned with their capacities (economic power, population, population policy, demographic structure, possibility of social-engineering ...). This way accepting more than a million migrants into the European family of 500 million people would not be a problem (Schmid, 2016:15).

\section{Increasing the capacity of "Frontex"}

Time appears as a factor with a special impact on admissibility and effectiveness, often as a limiting factor. Solutions that are acceptable for a shorter period of time need not be successful for a longer period and vice versa. The organization for the control of European borders - Frontex, until recently had only 310 employees and a budget of 114 million euros. Current requirements that are placed before this organization require increasing the capacity and resources of the same. The possibility of holding on to the Schengen agreement will be conditioned by the ability of all member states, particularly the Mediterranean countries (Italy and Greece), which are under constant constant pressure from migrants for many years. 


\section{Introducing innovative solutions in the process of dealing with the migrant population}

The migrant crisis, whose maximum was reached in 2015 , has shown the necessity of introducing innovative solutions in the process of acceptance and care of migrants (Schmid, 2016: 9) ${ }^{23}$, as well as in the discovery of radicalized individuals within the refugee population (DW, 2017) ${ }^{24}$. The German Migration Office has reported that the identity of 400,000 people is not known, while 130,000 asylum seekers who at some point entered Germany were "gone" and became invisible to the security and civil sector - some of them have probably moved to other countries (Schmid, 2016:44).

Globalization processes are accompanied by an increasing influence of multi-national companies whose main driving force (profit) sees the migrant crisis as a potential source of income by offering new solutions. Erick Prince, a close associate of Trump Administration, offered the services of his own company, Frontier Services Group, in stopping and returning hundreds of thousands of migrants seeking their "luck" coming to Europe from Libya. Noting that this company will close the migration channel, for only a fraction of the funds that the EU spends for the Frontex forces that are trying to close the migration channel through the Mediterranean Sea. (Blic, 2017)

23 During the reception of migrants, the German police managed to take fingerprints of about 10 percent of the migrant population.

24 Since the Berlin Christmas attack, members of the German Criminal Investigation Service (BKA) are applying a completely new analytical system called Radar-iTE, which presents a questionnaire on socialization and the attitude of violence. The purpose of the questionnaire is to gather information about the suspect. The system should serve to detect particularly dangerous and radicalized persons, thus the service should focus on the supervision of these people.
The offered alternatives represent only technical solutions in stopping migration and cross-cutting of terrorism. It is necessary to find solutions that will enable the management of migrant populations to prevent terrorism. Alex Schmid, a UN official, points out two measures that need to be taken:

First: asking the asylum-seekers in Europe to publicly commit themselves to the respect of the laws of the host country, its political culture and key European values (the rule of majority democracy with respect for minority rights, the rule of law, human rights, freedom of thought, social solidarity, pluralism and mutual tolerance)

And Secondly: oblige them to assist the authorities in the process of identifying potential terrorists (operative-perpetrators of terrorist acts, persons recruiting new members or persons wishing to join terrorist organizations) (Schmid, 2016:51).

The idea of a deradicalization process that was accepted by the West with great enthusiasm collapses when faced with the results of the implemented measures (Mohamed, 2018) ${ }^{25}$, regardless of the high use of material resources (Kern, $2017)^{26}$ and significant engagement of state institutions.

25 Deradialisation programs conducted in Great Britain, as claimed by the "Behavioural Insights Team" partly owned by the British government, are at best ineffective and at worst counter productive. This company has analyzed 33 programs and according to their conclusions only two programs were successful.

26 Preliminary reports on the deradicalisation programs that have been carried out reveal that the French government has nothing to show for tens of millions of euros spent in the fight against Islamic radicalization. 
The possibility of directing the migrant population in such a way, followed by collecting and adequate exchange of information on disguised and radical- ized activists of terrorist organizations would enable a more secure operation of the whole security sector of the EU..

\section{CONCLUSION}

The threat of terrorism is increasingly present and affecys both the individual states and the entire international community. The US-Russia coalition (first after the Second World War), assisted by China's logistical efforts in the process of neutralizing the self-proclaimed Islamic State of Iraq and Levant - ISIL ${ }^{27}$, merely confirm the necessity of the process of neutralizing this global danger, which the international community has repeatedly mentioned.

The areas of North Africa and the Middle East, pressed by decades of national turmoil, socio-economic problems and military interventions of various coalitions led by the United States, as well as the frequent use of terrorism as an answer to a more powerful enemy, have produced an enormous population of migrants.

It is undeniable that migration caused by frequent terrorist activities (which in the areas such as Iraq and Afghanistan represent the so-called "push" factor), or the use of migration channels for proven infiltration of radicalized members of terrorist organizations, unambiguously prove the existence of interaction between these social phenomena. According to the authors of this paper, the increase in the migration of the population from the war-affected area, where the

$\overline{27 \text { ISIL represents }}$ an unrecognized state, a jihadist paramilitary formation, which controlled large parts of Iraq and Syria. It draws its roots from Sunni fundamentalist groups that began in Iraq in early 2004, after the US invasion. most significant terrorist organizations exist, also increases the risk of terrorist activity, which confirms the causal relationship between the growth of migration movements and terrorism in the EU. All transit countries are exposed to this type of risk, particularly those that are the ultimate destination of migrant population, tohse that have a heterogeneous population with a high percentage of Muslims (Brussels) (Anastasijević, 2015) ${ }^{28}$, Clichy (Paris) (Đorić, 2018:58) ${ }^{29}$ and countries taking part in military interventions in the states of origin for the migrants (France and Great Britain).

Migration movements and terrorist activities are becoming more and more complex. The new emerging forms of terrorism and migration, created in the imagination of their inspirators and organizers, necessitate a constant adaptation and finding of new ways and methods in countering these social phenomena. The EU's appropriate response to the process of resolving the migrant crisis and its terrorism-related activities will primarily depend on EU consensus policy. Such a policy will enable increasing the EU's capacity and introducing innovative solutions in the process of monitoring and controlling the migrant population, particularly in the detec-

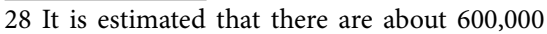
Muslims living in Belgium today, or $6 \%$ of the total population (in Brussels there are 25\% of them), of which half are Moroccans, and a quarter are Turks and Kurds.

29 The suburbs of Paris, where 90 percent of the immigrant families live. 
tion of radicalized members. Innovative solutions will also require a choice between European political values (Mijalković, Petrović, 2016:14) $)^{30}$ and security,

30 At the moment, the world, Europe more so than anyone else, is faced with a great and, first of all, serious contradictory dilemma of choice between: the freedom of global movement of people, goods and capital, which is considered to be an advanced democratic practice, against the restriction of the waves of economic migrants and (false) refugees; asylum seekers from central Eurasia, whose freedom of movement it is trying to limit because they are allegedly threatening the interests of European states, which is contrary to democratic trends. due to the necessity of finding solutions that successfully deal with terrorism and migration, minimizing the listed values (Rapoport, 2002:271).

At the ends of this spectrum, which democratic societies will face, there will be privacy and security. The future is likely to require the restriction of some human rights that we perceive as fundamental, either at the expense of the migrant population or the EU citizens, in order to reach a consensus on preserving security.

\section{REFERENCES}

1. Anastasijević, D. Srce tame. https: //www. vreme. com/cms/view. php?id=1347129. (31.05.2018)

2. Attack on Nice: Who was Mohamed Lahouaiej-Bouhlel. http://www.bbc.com/ news/world-europe-36801763. (19.02.2018.)

3. Beriša, H., \& Rakić, M. (2016). Migrantska kriza-Studija slučaja Republike Srbije. Kultura polisa, br. 30: 35-60.

4. Čerin, S. "Deca džihada”, najjače oružje u rukama terorista. https://rs.sputniknews. com/analize/201701031109489402-Deca-dzihadisti-Bliski-istok/. (23.03.2018.)

5. de Wenden, C.W. (2016). Irregular Migration in France. U: A. Triandafyllidou (Ur.), Irregular Migration in Europe: Myths and Realities. Routledge.115-124. doi:10.4324/9781315589848

6. Despotović, D. (2016). Geopolitički i demografski aspekti aktuelne migrantske krize. Kultura polisa, 30: 11-28.

7. Dragojlović, J., \& Jovanović, M. (2016). Migrantska kriza - bezbednosni izazovi, rizici i pretnje. Kultura polisa, 30: 61-70.

8. Gajić, A. (2016). Geopolitika sirijskih migracija i EU. Kultura polisa, 30: 21-33.

9. Giddens, A. (1988). Posledice modernosti. Beograd: Filip Višnjić.

10. Global terrorism index. (2017). Institute for economics and peace. http://www. economicsandpeace.org; 5th ed.; [Pristupljeno 30. maja 2018.].

11. Gospodar rata dao ponudu Evropi. https://www.blic.rs/vesti/svet/gospodar-ratadao-ponudu-evropi-zaustavicu-migrante-za-samo-deo-cene-koju-vec-placate/ fcspz74. (25.05.2018.)

12. Hasan, H. What awaits Syrian refugees in 2018. https://www.middleeastmonitor. com/20180111-what-awaits-syrian-refugees-in-2018/ (27.02.2018.)

13. Hoffman, B. (1998). Inside Terrorism. New York: Columbia University Press. 
14. https://www.srbijadanas.com/clanak/glavni-borci-islamista-su-deca-teroristi-se-oslanjaju-na-decu-vojnike-uznemirujuci-video-16.

15. Islamic State and the crisis in Iraq and Syria in maps. http://www.bbc.com/news/ world-middle-east-27838034. (27.02.2018.)

16. Kern, S. Sumorna demografska budućnost Nemačke. http://www.nspm.rs/savremeni-svet/demografska-buducnost-nemacke.html?alphabet=l. (01.09.2018.)

17. Kern, S. France: Deradicalization of Jihadists "Total Fiasco". https://www.gatestoneinstitute.org/9982/france-deradicalization. (14.03.2019.)

18. Lečić, B. (2017). Aktuelne migracije ka Evropi i problem terorizma. Kultura polisa, br. 2: 95-116; posebno izdanje

19. Mihić, B. (2016). Migracije - od krijumčarenja migranata do "velike seobe naroda”. Nacionalna bezbednost, 109-127.

20. Mijalković, S., \& Petrović, I. (2016). Bezbednosni rizici savremenih. NBP - žurnal za kriminalistiku i pravo, br. 2: 1-19.

21. Mijalković, S. (2016). Izazovi identiteta u kontekstu terorističkih napada "Pariz 2015”. NBP - žurnal za kriminalistiku i pravo, br. 1: 24-45.

22. Mohamed, A.Z. Why Britan's Deradicalization Programs Are Failing. https:// www.gatestoneinstitute.org/.../britain-deradicalization-pr.... (14.03.2019.)

23. Naučno "filtriranje" radikalnih islamista. http://www.dw.com/sr/nau\%C4\%8Dno-filtriranje-radikalnih-islamista/a-41884193. (19.03.2019.)

24. Neumann, P.R. (2014). The New Jihadism: Global Snapshot. London: The International Centre for the Study of Radicalisation and Political Violence (ICSR).

25. Number of casualties due to terrorism worldwide between 2006 and 2017. https://www.statista.com/statistics/202871/number-of-fatalities-by-terrorist-attacks-worldwide/. (13.02.2018.)

26. Parezanović, M. Sirija i "arapsko proleće". http://www.nspm.rs/savremeni-svet/ sirija-i-arapsko-prolece.html?alphabet=l. (10.10.2018.)

27. Pavlićević, P.D. (2016). Migrantska kriza - evropsko javno mnjenje i proces integracije imigracione populacije. Kultura polisa, 31: 57-70.

28. Rapoport, D.C. (2002). The Four Waves of Rebel Terror and September 11. Anthropoetics, $8(1)$; 36-52.

29. Robbins, J. Does Military Intervention Increase the Terror Threat. https: //www. bbc. com/news/uk-40061551 (10.10.2018.)

30. Rusi upozoravaju - "Teroristi IS-a su u Afganistanu i imaju više od 10.000 boraca, a SAD ih podcjenjuje". https://dnevnik.hr/vijesti/svijet/rusi-upozoravaju-teroristi-islamske-drzave-u-afganistanu-imaju-vise-od-10-000-boraca-a-amerika-ih-podcjenjuje---500946.html. (28.05.2018.)

31. Schmid, A.P. (2016). Links Between Terrorism and Migration: An Exploration. Terrorism and Counter-Terrorism Studies, doi:10.19165/2016.1.04

32. Sedeberg, P. (2002). Global Terrorism: Problems of Challenge and Response. U C.W. Kegley (Ur.), The New Global Terrorism. Cambridge: Pearson. 267-284. 
33. See, S. (2018). Returning Foreign Terrorist Fighters: A Catalyst for Recidivism among Disengaged Terrorists. Counter Terrorist Trends and Analyses, Vol. 10; No. 6: 7-15.

34. Silke, A. (2003). Terrorists, Victims and Society: Psychological Perspectives on Terrorism and its Consequences. Chichester, UK: John Wiley and Sons. doi:10.1002/9780470713600

35. Simeunović, D. (2017). Migraciona kriza kao bezbednosni izazov za zemlje zapadnog Balkana - stanje u 2017. i perspektiva. Kultura polisa, posebno izdanje, br. 2: 31-56.

36. Simeunović, D. (2015). Migracije kao uzrok političkih anomalija u evropi. NBP - žurnal za kriminalistiku i pravo, br. 3: 1-18.

37. Stern, J., \& Mcbride, M.K. (2013). Terrorism after the 2003 Invasion of Iraq. Providence: Brown University - Watson Institute for International and Public Affairs. http://watson.brown.edu/costsofwar/files/cow/imce/papers/2013/Terrorism\%20after\%20the\%202003\%20Invasion\%20of\%20Iraq.pdf.

38. Trump's Jerusalem Decision: Implications and Consequences. https://www.wilsoncenter.org/event/trumps-jerusalem-decision-implications-and-consequences. (27.02.2018.)

39. Voronkova, A. (2017). Editor's Introduction. Armed Conflict Survey, 3(1), 5-12. doi:10.1080/23740973.2017.1311537

40. Zwitter, A. (2011). Human Security, Law and the Prevention of Terrorism. Milton Park: Routledge.. 